Check for updates

Cite this: New J. Chem., 2020, 44,6063

Received 11th February 2020, Accepted 29th March 2020

DOI: 10.1039/d0nj00725k

\section{Salalen vs. thiolen: in the ring(-opening of epoxide and cyclic carbonate formation) $\dagger$}

\author{
Oliver J. Driscoll, Jack A. Stewart, Paul McKeown (D) and Matthew D. Jones (D)* \\ A range of $\mathrm{Fe}(\mathrm{III})$-salalen and -thiolen-chloride complexes have been prepared and are shown to be \\ active catalysts for the selective coupling of $\mathrm{CO}_{2}$ and cyclohexene oxide ( $\mathrm{CHO}$ ). The first Fe(III)-thiolen- \\ acetate complex is also reported. The effect of the structure of the complex on activity is explored. An \\ epoxide substrate scope is also provided, using the most active catalyst, as well as a study into the effect \\ of co-catalyst equivalents on activity and selectivity.
}

rsc.li/njc

\section{Introduction}

Two contemporary, rapidly growing areas of green chemistry involve the use of sustainable metal complexes, such as iron, for catalysis and catalytic transformations involving $\mathrm{CO}_{2}$, ideally utilising a waste stream as part of a 'circular economy' approach. ${ }^{1-12}$ The coupling of $\mathrm{CO}_{2}$, a renewable, abundant, cheap, non-toxic, 'waste' material, with reactive epoxides enables the formation of cyclic organic carbonates (COCs) and/or aliphatic polycarbonates (APCs). ${ }^{3,4,7-9,13-20}$ COCs are used in a range of applications including: high boiling, polar aprotic solvents; lithium-ion battery electrolytes; plasticisers; anti-foam additives; intermediates in both organic synthesis and industry and as monomers for copolymerisation with cyclic esters. ${ }^{7,8,14,15,21-23}$ This is a more sustainable method compared to the use of highly toxic phosgene employed in the traditional synthesis. ${ }^{8,14,16,17}$ Examples for the selective and effective Fe-mediated $\mathrm{CO}_{2}$ /epoxide coupling reaction remain less prevalent than complexes containing metals such as $\mathrm{Mg}, \mathrm{Cr}, \mathrm{Co}, \mathrm{Zn}$ and $\mathrm{Al}^{15,22-33}$ This is despite the numerous benefits associated with iron such as high abundance, low toxicity and low commercial and industrial cost. ${ }^{1,2,5}$

Della Monica et al. recently reviewed a variety of ligand classes complexed to iron such as salalen $\{\mathrm{ONNO}\}$ and phenoxythioether $\{$ OSSO $\} .^{7}$ Lamberti and co-workers reported the first example of a $\mathrm{Fe}(\mathrm{III})$-salalen-chloride complex, together with Fe-salen and -salan complexes, for $\mathrm{CO}_{2} /$ epoxide coupling. ${ }^{28}$ More recently, we reported examples of air-stable Fe(III)-acetate complexes with salalen, salan and salen ligands for the selective coupling of $\mathrm{CO}_{2}$ with a series of epoxides, predominantly

Department of Chemistry, University of Bath, Claverton Down, Bath, BA2 7AY, UK. E-mail:mj205@bath.ac.uk

$\dagger$ Electronic supplementary information (ESI) available. CCDC 1980459. For ESI and crystallographic data in CIF or other electronic format see DOI: 10.1039/d0nj00725k cyclohexene oxide (CHO). ${ }^{34}$ cis-Cyclohexene carbonate (cis-CHC) was formed as the exclusive product under mild, solvent-free conditions $\left(80^{\circ} \mathrm{C}, 10 \mathrm{bar} \mathrm{CO}_{2}, 0.08 \mathrm{~mol} \%\right.$ metal loading). This is rare in the literature due to the bicyclic ring strain of $\mathrm{CHC}$ and the challenging nature of the internal $\mathrm{CHO}$ epoxide which imparts steric hindrance and regioselectivity issues associated with the possibility of four different products.

Della Monica, Capacchione and co-workers have reported a variety of mononuclear and dinuclear Fe(II/II)-bis(thioether)phenolate $\{\mathrm{OSSO}\}$ complexes with two hemilabile sulfur donor atoms. ${ }^{7,21,35,36}$ Indeed, the application of the mononuclear $\mathrm{Fe}(\mathrm{III})$-bis(thioether)-diphenolate complexes with an onium salt co-catalyst achieved very high TOFs and selectivity under mild conditions at 1 bar $\mathrm{CO}_{2}$ for a large range of internal and terminal epoxide substrates. ${ }^{21}$ For example, the conversion of propylene oxide (PO) to propylene carbonate (PC) achieved a TOF of $290 \mathrm{~h}^{-1}$ at $35^{\circ} \mathrm{C}$ and 1 bar $\mathrm{CO}_{2}$. However, the cis-CHC product was not observed with $\mathrm{CHO}$ and a TBAC co-catalyst, instead polycyclohexene carbonate (PCHC) was selectively formed. ${ }^{21}$

We recently reported the synthesis of a range of $\mathrm{Fe}(\mathrm{III})-$ salalen-chloride $\{\mathrm{ONNO}\}$ and $\mathrm{Fe}(\mathrm{III})$-thiolen-chloride $\{\mathrm{ONSO}\}$ complexes and their application to the isoselective ring-opening polymerisation (ROP) of rac-lactide. ${ }^{37,38}$ In particular, there are scarce examples of the 'thiolen', imine-thiobis(phenolate), family of ligands, ${ }^{39,40}$ and they have not been applied to $\mathrm{CO}_{2} /$ epoxide coupling despite the similarities to Della Monica's bis(thioether)-phenolate $\{$ OSSO $\}$ complexes.

Herein, this work represents the application of previously synthesised $\mathrm{Fe}$ (III)-salalen-chloride and $\mathrm{Fe}(\mathrm{III})$-thiolen-chloride complexes (Scheme 1) to the selective coupling of $\mathrm{CO}_{2}$ and epoxides. Furthermore, a new Fe(III)-thiolen-acetate complex is reported, applied and fully characterised through High-Resolution MassSpectrometry (HR-MS) and single crystal XRD. The most effective catalyst was tested with a range of epoxide substrates and co-catalyst 


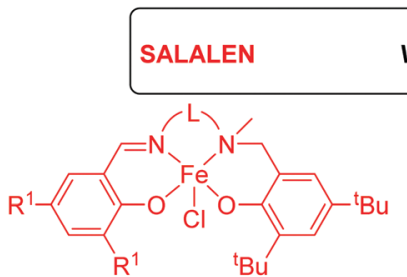

$\mathrm{Fe}(\mathbf{A}) \mathrm{R}^{1}=\mathrm{H}, \mathrm{L}=-\mathrm{CH}_{2} \mathrm{CH}_{2}-$

$\mathrm{Fe}$ (B) $\mathrm{R}^{1}=\mathrm{Me}, \mathrm{L}=-\mathrm{CH}_{2} \mathrm{CH}_{2}-$

$\mathrm{Fe}$ (C) $\mathrm{R}^{1}={ }^{\mathrm{B}} \mathrm{Bu}, \mathrm{L}=-\mathrm{CH}_{2} \mathrm{CH}_{2}-$

$\mathrm{Fe}$ (D) $\mathrm{R}^{1}=\mathrm{Cl}, \mathrm{L}=-\mathrm{CH}_{2} \mathrm{CH}_{2}-$

$\mathrm{Fe}$ (E) $\mathrm{R}^{1}={ }^{\mathrm{t}} \mathrm{Bu}, \mathrm{L}=-\mathrm{C}_{6} \mathrm{H}_{4^{-}}$

$\mathrm{Fe}(\mathbf{F}) \mathrm{R}^{1}={ }^{\mathrm{t}} \mathrm{Bu}, \mathrm{L}=-\mathrm{CH}_{2} \mathrm{C}_{5} \mathrm{H}_{9}$ -

$\mathrm{Fe}(\mathbf{G}) \mathrm{R}^{1}={ }^{\mathrm{t}} \mathrm{Bu}, \mathrm{L}=-\mathrm{C}_{6} \mathrm{H}_{10^{-}}$

Scheme 1 Salalen $[\mathrm{Fe}(\mathbf{A}-\mathbf{G})]$, and thiolen $[\mathrm{Fe}(\mathbf{1}-\mathbf{6})]$ complexes used in this study.

concentrations. Modification of the ligand structure allows for comparison between donor atoms $(\mathrm{N} / \mathrm{S})$ as well as sterics and electronics.

\section{Results and discussion}

The $\mathrm{Fe}(\mathrm{III})$ chloride complexes bearing salalen $[\mathrm{Fe}(\mathbf{A}-\mathbf{G})]$ and thiolen $[\mathrm{Fe}(\mathbf{1 - 5})]$ ligand $^{39-44}$ have been previously synthesised (Scheme 1), ${ }^{37,38}$ and were screened for $\mathrm{CO}_{2}$ /epoxide coupling with distilled CHO. Additionally, one Fe(III)-thiolen-acetate complex [Fe(6)] (Fig. 1) has been synthesised with the identity of the $\mathrm{ML}^{+}$ion confirmed by ESI-MS. The solid-state structure of $\mathrm{Fe}(6)$ displays a distorted pseudo-trigonal bipyramidal geometry $\left(\tau_{5}=0.63\right)$ with an equatorial site occupied by an acetate auxiliary group (Fig. 1). Although this geometry leans closer to a square-based pyramid compared with $\mathrm{Fe}(2)\left(\tau_{5}=0.78\right)$, bearing a chloride auxiliary group, ${ }^{38,45}$ it is similar to the salalen complex, $\mathrm{Fe}(\mathbf{C})$, and the acetate auxiliary group analogue $\left\{\mathrm{Fe}(\mathbf{C}), \tau_{5}=0.66\right.$ and ' $\mathrm{Fe}(\mathbf{C}) \mathrm{OAc}$ ', $\left.\tau_{5}=0.65\right\} .{ }^{34,37}$ We have previously reported a

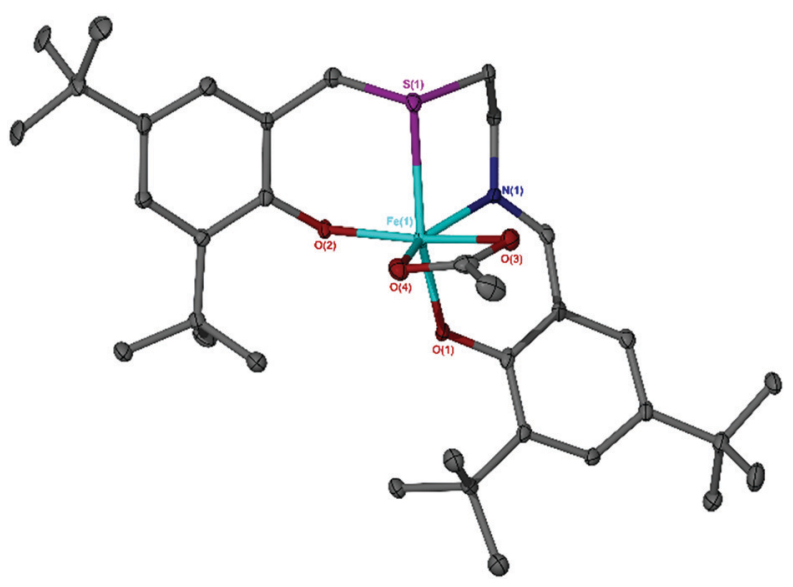

Fig. 1 Solid state structure of $\mathrm{Fe}(\mathbf{6})$, ellipsoids shown at 30\% probability level. Selected bond lengths ( $(\AA)$ and angles $\left(^{\circ}\right)$ : $\mathrm{Fe}-\mathrm{O}(1)=1.887(3), \mathrm{Fe}-\mathrm{O}(2)=$ 1.873(3), $\mathrm{Fe}-\mathrm{N}(1)=2.077(4), \mathrm{Fe}-\mathrm{S}(1)=2.5904(17) ; \mathrm{O}(1)-\mathrm{Fe}-\mathrm{N}(1)=87.64(14)$, $\mathrm{O}(2)-\mathrm{Fe}-\mathrm{N}(1)=109.78(14), \mathrm{N}(1)-\mathrm{Fe}-\mathrm{S}(1)=81.07(12), \mathrm{O}(1)-\mathrm{Fe}-\mathrm{S}(1)=$ 168.43(10), O(2) $-\mathrm{Fe}-\mathrm{C}($ acetate $)=130.40(17)$. carbonato-bridged dimer arising from the recrystallisation of $\mathrm{Fe}(2)$ in air and suggested that it could represent an intermediate in halide free $\mathrm{CO}_{2}$ /epoxide coupling as reported by Muller and coworkers. $^{38,46}$

The reactions were performed, using previously reported conditions, ${ }^{34,47}$ at a low catalyst loading of $0.08 \mathrm{~mol} \%$ and $0.64 \mathrm{~mol} \%$ tetrabutylammonium chloride (TBAC) co-catalyst loading in solvent-free conditions at $80{ }^{\circ} \mathrm{C}$ and 10 bar $\mathrm{CO}_{2}$ for $24 \mathrm{~h}$ (Table 1). The reaction mixtures changed colour from purple to red over the course of the reaction; this has previously been attributed to the formation of $\mu$-oxo-bridged Fe(III) species. $^{22,34}$

Aliquots of the crude product mixtures were taken and analysed using ${ }^{1} \mathrm{H}$ NMR spectroscopy to determine the conversion, product selectivity and TOF values through integration of the methine proton resonance signals for cis-cyclohexene carbonate (cis-CHC), trans-cyclohexene carbonate (trans-CHC), polycyclohexene carbonate (PCHC) and polycyclohexene oxide (PCHO) respectively relative to unreacted $\mathrm{CHO}$. At $80{ }^{\circ} \mathrm{C}$, the strained bicyclic cis-CHC product was formed exclusively for all complexes, with the exception of $\mathrm{Fe}(\mathbf{4})$, which is rare in the literature.

A range of techniques were applied to corroborate the findings from ${ }^{1} \mathrm{H}$ NMR spectroscopy. ESI-MS of the crude product mixtures was used to confirm the presence of cyclic CHC. Although ESI-MS is unable to differentiate between the cis- and trans-CHC, ${ }^{1} \mathrm{H}$ NMR spectroscopy identifies the methine resonance signals with cis-CHC appearing at $\delta 4.66 \mathrm{ppm}$ and trans-CHC at $\delta 3.99 \mathrm{ppm}$, in agreement with that previously reported. ${ }^{23}$ The characteristic methine resonance associated with $\mathrm{PCHC}$ is reported to appear at $\delta 4.65 \mathrm{ppm}$

Table $1 \mathrm{CO}_{2} / \mathrm{CHO}$ reaction catalysed by $\mathrm{Fe}(\mathbf{A}-\mathrm{G} \& \mathbf{1 - 6})$ with TBAC
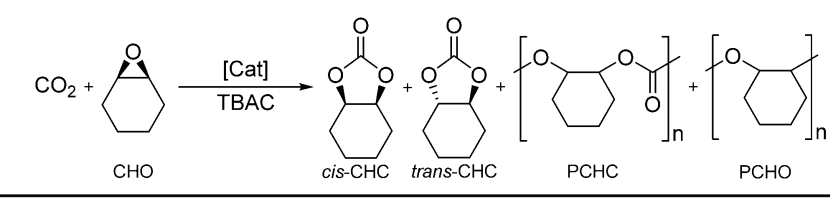

cis-CHC : trans-

Selectivity CHC : PCHC : Entry Catalyst Conv. ${ }^{a} \%$ for cis-CHC $^{a} / \%$ PCHO ratio $/ \%$ TOF TO $^{b} / \mathrm{h}^{-1}$

\begin{tabular}{|c|c|c|c|c|c|}
\hline 1 & $\mathrm{FeCl}_{3}$ & 44 & 83 & $83: 10: 16$ & 23 \\
\hline 2 & None & 43 & 83 & $83: 0: 0: 17$ & 22 \\
\hline 3 & $\mathrm{Fe}(\mathbf{A})$ & 53 & $>99$ & $>99: 0: 0: 0$ & 28 \\
\hline 4 & $\mathrm{Fe}(\mathbf{B})$ & 47 & $>99$ & $>99: 0: 0: 0$ & 28 \\
\hline 5 & $\mathrm{Fe}(\mathbf{C})$ & 41 & $>99$ & $>99: 0: 0: 0$ & 21 \\
\hline 6 & $\mathrm{Fe}(\mathbf{D})$ & 44 & $>99$ & $>99: 0: 0: 0$ & 23 \\
\hline 7 & $\mathrm{Fe}(\mathbf{E})$ & 46 & $>99$ & $>99: 0: 0: 0$ & 24 \\
\hline 8 & $\mathrm{Fe}(\mathbf{F})$ & 48 & $>99$ & $>99: 0: 0: 0$ & 25 \\
\hline 9 & $\mathrm{Fe}(\mathbf{G})$ & 51 & $>99$ & $>99: 0: 0: 0$ & 27 \\
\hline 10 & $\mathrm{Fe}(\mathbf{1})$ & 47 & $>99$ & $>99: 0: 0: 0$ & 24 \\
\hline 11 & $\mathrm{Fe}(2)$ & 43 & $>99$ & $>99: 0: 0: 0$ & 22 \\
\hline 12 & $\mathrm{Fe}(3)$ & 54 & $>99$ & $>99: 0: 0: 0$ & 28 \\
\hline 13 & $\mathrm{Fe}(4)$ & 51 & 90 & $90: 1: 0: 9$ & 27 \\
\hline 14 & $\mathrm{Fe}(5)$ & 60 & $>99$ & $>99: 0: 0: 0$ & 31 \\
\hline $15^{c}$ & $\mathrm{Fe}(5)$ & 75 & 94 & $94: 1: 0: 5$ & 156 \\
\hline 16 & $\mathrm{Fe}(\mathbf{6})$ & 44 & $>99$ & $>99: 0: 0: 0$ & 23 \\
\hline
\end{tabular}

Conditions: [Fe] catalyst (0.08 mol\%, 1 eq.), TBAC (0.64 mol\%, 8 eq.), CHO $(5.0 \mathrm{~mL}), 10$ bar $\mathrm{CO}_{2}, 80{ }^{\circ} \mathrm{C}, 24 \mathrm{~h} .{ }^{a}$ Determined via ${ }^{1} \mathrm{H}$ NMR spectroscopy using the methine resonances of $c i s-\mathrm{CHC}(\delta=4.66 \mathrm{ppm})$, trans-CHC $(\delta=3.99 \mathrm{ppm})$ and PCHO $(\delta=3.35 \mathrm{ppm}) .{ }^{b}$ TOF $=[$ [Conv. $\% / 100) \times(100 / 0.08 \mathrm{~mol} \%)] / 24 \mathrm{~h}=[($ Conv. $/ 100) \times 1250] / 24 .{ }^{c} 120{ }^{\circ} \mathrm{C}, 6 \mathrm{~h}$. 
which is very close to the desired cis-CHC product. ${ }^{23}$ To confirm the identity of the signal and that no polymer (PCHC) was formed, GPC analysis was carried out which showed no evidence of polymer formation. Therefore, ${ }^{1} \mathrm{H}$ NMR spectroscopy, ESI-MS and GPC analysis confirmed that cis-CHC was formed as the exclusive product.

Control reactions were carried out and activity was observed using the $\mathrm{FeCl}_{3}$ synthetic metal precursor with TBAC co-catalyst (Table 1, entry 1). Although cis-CHC remained the major product, two additional products were present and identified as trans$\mathrm{CHC}$, the thermodynamic product, and $\mathrm{PCHO}$, formed via polymerisation of the epoxide without $\mathrm{CO}_{2}$ insertion. This PCHO sideproduct was also produced when TBAC co-catalyst was used without any $[\mathrm{Fe}]$ catalyst (Table 1 , entry 2). No reaction was observed when [Fe] catalyst was used without co-catalyst; the TBAC being required to open the epoxide and initiate the catalytic cycle (Table 2 , entry 1 ).

The increase of steric bulk at $\mathrm{R}^{1}$, for both salalen and thiolen complexes, decreased conversion $\left\{\mathrm{Fe}(\mathbf{A}), \mathrm{R}^{1}=\mathrm{H}, 53 \%\right.$ vs. $\mathrm{Fe}(\mathbf{B})$, $\mathrm{R}^{1}=\mathrm{Me}, 47 \%$ vs. $\mathrm{Fe}(\mathrm{C}), \mathrm{R}^{1}={ }^{t} \mathrm{Bu}, 41 \%$ and $\mathrm{Fe}(\mathbf{1}), \mathrm{R}^{1}=\mathrm{H}, 47 \%$ vs. $\mathrm{Fe}(2), \mathrm{R}^{1}={ }^{t} \mathrm{Bu}, 44 \%$ respectively $\}$ but maintained product selectivity at $>99 \%$ for the cis-CHC. Thiolen complexes were generally more active than their salalen counterparts with the exception of the unsubstituted analogues $\left\{\mathrm{Fe}(\mathbf{A}), \mathrm{R}^{1}=\mathrm{H}, 53 \%\right.$ vs. $\left.\mathrm{Fe}(\mathbf{1}), \mathrm{R}^{1}=\mathrm{H}, 47 \%\right\}$. This was proposed to be due to the softer sulfur donor atom being more labile allowing for more space around the Fe(III) centre for the binding of epoxide, enhancing the reactivity. Similar observations were made for the comparisons of $\mathrm{Fe}(\mathrm{III})$-salalen and -thiolen complexes when applied to the ROP of lactide. ${ }^{37,38}$ Thiolen complex $\mathrm{Fe}(\mathbf{6})$, bearing ${ }^{t} \mathrm{Bu}$ substituents and an acetate auxiliary ligand, displayed similar activity to the analogous chloride complex $\{\mathrm{Fe}(2), \mathrm{X}=\mathrm{Cl}, 43 \%$ vs. $\mathrm{Fe}(6), \mathrm{X}=\mathrm{OAc}, 44 \%\}$. This is in contrast to the substituted $\mathrm{Fe}(\mathrm{III})$-salalen-chloride/acetate complexes previously investigated, where the acetate complex was more active. ${ }^{34}$

For the salalen complexes, modifying the ethylene backbone by installing a planar phenyl ring increased activity $\{\mathrm{Fe}(\mathbf{C}), \mathrm{L}=$ $-\mathrm{CH}_{2} \mathrm{CH}_{2}{ }^{-}, 41 \%$ vs. $\left.\mathrm{Fe}(\mathbf{E}), \mathrm{L}=-\mathrm{C}_{6} \mathrm{H}_{4}-, 46 \%\right\}$ and this is further emphasised when using a more rigid aminopiperidine backbone $\left\{\mathrm{Fe}(\mathbf{F}), \mathrm{R}^{1}=-\mathrm{CH}_{2} \mathrm{C}_{5} \mathrm{H}_{9^{-}}, 48 \%\right\}$. Moving from the ethylene backbone to a sterically hindered cyclohexane ring had minimal

Table $2 \mathrm{CO}_{2} / \mathrm{CHO}$ reaction catalysed by $\mathrm{Fe}(\mathbf{5})$ and various equivalents of TBAC

\begin{tabular}{|c|c|c|c|c|c|}
\hline Entry & $\begin{array}{l}\text { Eq. of } \\
\text { TBAC }\end{array}$ & Conv. ${ }^{a} / \%$ & $\begin{array}{l}\text { Selectivity } \\
\text { for cis-CHC } / \%\end{array}$ & $\begin{array}{l}\text { cis-CHC: } \text { trans- }^{-} \\
\text {CHC : PCHC: } \\
\text { PCHO ratio }{ }^{a} / \%\end{array}$ & $\mathrm{TOF}^{b} / \mathrm{h}^{-1}$ \\
\hline 1 & 0 & 8 & 0 & $0: 0: 0:>99$ & 4 \\
\hline 2 & 2 & 8 & 79 & $79: 8: 0: 13$ & 4 \\
\hline 3 & 4 & 42 & 94 & $94: 4: 0: 2$ & 22 \\
\hline 4 & 8 & 60 & $>99$ & $>99: 0: 0: 0$ & 31 \\
\hline
\end{tabular}

Conditions: [Fe] catalyst (0.08 mol\%, 1 eq.), TBAC, CHO $(5.0 \mathrm{~mL}), 10 \mathrm{bar}$ $\mathrm{CO}_{2}, 80{ }^{\circ} \mathrm{C}, 24$ h. ${ }^{a}$ Determined via ${ }^{1} \mathrm{H}$ NMR spectroscopy using the methine resonances of cis-CHC ( $\delta 4.66 \mathrm{ppm})$, trans-CHC $(\delta 3.99 \mathrm{ppm})$ and PCHO $(\delta 3.35 \mathrm{ppm}) .{ }^{b}$ TOF $=[($ Conv. \%/100 $\left.) \times(100 / 0.08 \mathrm{~mol} \%)]\right]$ $24 \mathrm{~h}=[($ Conv. $/ 100) \times 1250] / 24$. effect on activity $\left\{\mathrm{Fe}(\mathbf{A}), \mathrm{R}^{1}=\mathrm{H}, \mathrm{L}=-\mathrm{CH}_{2} \mathrm{CH}_{2}-, 53 \%\right.$ vs. $\mathrm{Fe}(\mathbf{G})$, $\mathrm{R}^{1}=-\mathrm{C}_{6} \mathrm{H}_{10^{-}}, 51 \%$. The trends observed with the modification of backbone structure are in agreement with the $\mathrm{Fe}(\mathrm{III})$-acetate complexes previously reported. ${ }^{34}$

As expected, installing chloro-functionality at $\mathrm{R}^{1}$, thus increasing the Lewis acidity of the $\mathrm{Fe}(\mathrm{III})$ centre, increased conversion; the thiolen complex was moderately more active than the salalen $\left\{\mathrm{Fe}(\mathrm{D}), \mathrm{R}^{1}={ }^{t} \mathrm{Bu}, 44 \%\right.$ vs. $\left.\mathrm{Fe}(3), \mathrm{R}^{1}=\mathrm{Cl}, 54 \%\right\}$. The use of halide substitution was further explored using the $\mathrm{Fe}(\mathrm{III})$-thiolen complexes. Modifying the $\mathrm{R}^{1}$ position from a chloride to a heavier bromide slightly decreased activity, presumably due to a decrease in Lewis acidity at the $\mathrm{Fe}(\mathrm{III})$ centre $\left\{\mathrm{Fe}(3), \mathrm{R}^{1}=\mathrm{Cl}, 54 \%\right.$ vs. $\left.\mathrm{Fe}(4), \mathrm{R}^{1}=\mathrm{Br}, 51 \%\right\}$. Additionally, this was accompanied by a decrease in product selectivity to $90 \%$. Transferring the bromide to the thio-phenolate moiety $\left(\mathrm{R}^{2}\right)$ increased activity while maintaining the cis-CHC as the exclusive product $\left\{\mathrm{Fe}(5), \mathrm{R}^{2}=\mathrm{Cl}, 60 \%\right\}$. Indeed, this complex was found to be the most active in this study with a TOF value of $31 \mathrm{~h}^{-1}$; a TOF value similar to that reported by Lamberti using Fe(III)salalen, -salen, -salan-chloride complexes at $100{ }^{\circ} \mathrm{C}, 20$ bar $\mathrm{CO}_{2}$ for $22 \mathrm{~h}$ using $\mathrm{CHO}^{28}$ This value was increased to $156 \mathrm{~h}^{-1}$ by increasing the temperature to $120{ }^{\circ} \mathrm{C}$ and using a shorter reaction time of 6 hours (Table 1, entry 15). However, the formation of PCHO and trans-CHC decreased cis-CHC selectivity to $94 \%$.

The effect of using different equivalents of TBAC co-catalyst was explored using the most active catalyst, Fe(5) (Table 2). As mentioned previously, no reaction was observed with 0 eq. of TBAC (Table 2, entry 1). Increasing TBAC concentration improved the activity and also had a positive effect on selectivity; a mixture of products was observed using 2 and 4 eq. of TBAC (Table 2, entries 2 and 3). Increasing the TBAC loading to 8 eq. formed cis$\mathrm{CHC}$ as the only product $>99 \%$ and gave the highest TOF value at $80{ }^{\circ} \mathrm{C}\left(31 \mathrm{~h}^{-1}\right)$ (Table 2, entry 4). This underlines the importance of employing an elevated concentration of co-catalyst when targeting CHCs with this reaction. The formation of cis-CHC selectively has previously been reported and discussed in literature; the presence of co-catalyst and particularly excess co-catalyst favours the formation of carbonate anions after $\mathrm{CO}_{2}$ insertion. Therefore intramolecular ring-closing nucleophilic substitution, forming the cis-CHC product, is strongly favoured and potential competitive binding of further $\mathrm{CHO}$ and polymerisation is disfavoured (although PCHC is not observed in this study even when 0 eq. of TBAC was employed). ${ }^{23,47}$

High functional group tolerance was observed when $\mathrm{Fe}(5)$ and TBAC co-catalyst were applied to a substrate scope of commercially available, terminal epoxides (Table 3). As with the CHO reactions, identification of the product and determination of selectivity was achieved through a combination of ${ }^{1} \mathrm{H}$ NMR, GPC and ESI-MS. In all cases, the epoxide was selectively converted to the corresponding cyclic carbonate with moderate to high conversions. As expected, the least sterically hindered epoxide, propylene oxide (PO), was significantly more reactive than $\mathrm{CHO}(\mathrm{PO}, \mathrm{TOF}=$ $42 \mathrm{~h}^{-1}, \mathrm{CHO}$, TOF $=31 \mathrm{~h}^{-1}$ ). Styrene oxide (SO), bearing a bulky phenyl group, was closer in reactivity to $\mathrm{CHO}$, presumably as a result of similar steric profiles (TOF $=40 \mathrm{~h}^{-1}$ ). The addition of electron withdrawing groups increased reactivity, with the 
Table $3 \quad \mathrm{CO}_{2}$ coupled with various epoxides catalysed by $\mathrm{Fe}(\mathbf{5})$ and TBAC

\begin{tabular}{llll} 
Entry Epoxide & \multicolumn{3}{c}{$\begin{array}{l}\text { Product } \\
\text { Conv. }{ }^{a} / \%\end{array}$} \\
\hline selectivity $/ \%$ & $\mathrm{TOF}^{b} / \mathrm{h}^{-1}$ \\
\hline
\end{tabular}

Conditions: [Fe] catalyst ( $0.08 \mathrm{~mol} \%, 1$ eq.), TBAC (0.64 mol\%, 8 eq.), CHO $(5.0 \mathrm{~mL}), 10$ bar $\mathrm{CO}_{2}, 80{ }^{\circ} \mathrm{C}, 24 \mathrm{~h} .{ }^{a}$ Determined via ${ }^{1} \mathrm{H}$ NMR spectroscopy. ${ }^{b}$ TOF $=[($ Conv. $\% / 100) \times(100 / 0.08 \mathrm{~mol} \%)] / 24 \mathrm{~h}=[($ Conv. $/$ $100) \times 1250] / 24 .{ }^{c}$ Reduced reaction time of $18 \mathrm{~h}$.

exception of epichlorohydrin (ECH) $\left(\mathrm{TOF}=38 \mathrm{~h}^{-1}\right)$. Allylglycidyl ether (AGE) gave the highest conversion in $24 \mathrm{~h}$ (93\%); however, due to the solidification of phenoxymethyl ethylene carbonate, the reaction time with phenylglycidyl ether (PGE) was reduced to $18 \mathrm{~h}$ resulting in a higher TOF value (TOF $\left.=64 \mathrm{~h}^{-1}\right)$.

\section{Conclusions}

Fe(III) chloride complexes bearing a range of salalen and thiolen ligands were prepared and applied to the coupling of $\mathrm{CO}_{2}$ and CHO. Additionally, the first Fe(III)-thiolen-acetate was reported, fully characterised and also shown to be active for $\mathrm{CO}_{2}$ /epoxide coupling. With the exception of $\mathrm{Fe}(4)$, all catalysts gave cis-CHC as the exclusive product at $80{ }^{\circ} \mathrm{C}$. Thiolen complexes tended to be more active than their direct salalen counterparts and structure-activity-relationships were explored within the ligand classes. The most active catalyst, $\mathrm{Fe}(5)$, gave a TOF of $31 \mathrm{~h}^{-1}$ at mild conditions that could be increased to $156 \mathrm{~h}^{-1}$ when the temperature was raised to $120{ }^{\circ} \mathrm{C}$. A substrate scope of terminal epoxides demonstrated high functional group tolerance for $\mathrm{Fe}(5)$ and the importance of using 8 eq. of TBAC co-catalyst was highlighted.

\section{Conflicts of interest}

There are no conflicts to declare.

\section{Acknowledgements}

We would like to thank the University of Bath and the EPRSC (EP/L016443/1 and EP/P016405/1) for funding. We also thank Isabel Thomlinson for help with the graphical abstract. $\mathrm{MC}^{2}$ are also acknowledged for the use of their analytical facilities.

\section{References}

1 Iron Catalysis, ed. B. Plietker, Springer, Berlin, 2011, vol. 33.

2 M. Albrecht, R. Bedford and B. Plietker, Organometallics, 2014, 33, 5619-5621.

3 C. Martín, G. Fiorani and A. W. Kleij, ACS Catal., 2015, 5, 1353-1370.

4 M. North, B. Wang and C. Young, Energy Environ. Sci., 2011, 4, 4163-4170.

5 P. Chirik and R. Morris, Acc. Chem. Res., 2015, 48, 2495.

6 C. Darcel and J.-B. Sortais, Isr. J. Chem., 2017, 57, 1069.

7 F. Della Monica, A. Buonerba and C. Capacchione, Adv. Synth. Catal., 2019, 361, 265-282.

8 M. North, R. Pasquale and C. Young, Green Chem., 2010, 12, 1514-1539.

9 J. Artz, T. E. Müller, K. Thenert, J. Kleinekorte, R. Meys, A. Sternberg, A. Bardow and W. Leitner, Chem. Rev., 2018, 118, 434-504.

10 A. J. Hunt, E. H. K. Sin, R. Marriott and J. H. Clark, ChemSusChem, 2010, 3, 306-322.

11 J. A. Martens, A. Bogaerts, N. De Kimpe, P. A. Jacobs, G. B. Marin, K. Rabaey, M. Saeys and S. Verhelst, ChemSusChem, 2017, 10, 1039-1055.

12 E. S. Sanz-Pérez, C. R. Murdock, S. A. Didas and C. W. Jones, Chem. Rev., 2016, 116, 11840-11876.

13 T. Sakakura and K. Kohno, Chem. Commun., 2009, 1312-1330.

14 B. Schäffner, F. Schäffner, S. P. Verevkin and A. Börner, Chem. Rev., 2010, 110, 4554-4581.

15 A. Buonerba, A. De Nisi, A. Grassi, S. Milione, C. Capacchione and B. Rieger, Catal. Sci. Technol., 2015, 5, 118-123.

16 A.-A. G. Shaikh and S. Sivaram, Chem. Rev., 1996, 96, 951-976.

17 H. Büttner, L. Longwitz, J. Steinbauer, C. Wulf and T. Werner, Top. Curr. Chem., 2017, 375, 1-56.

18 V. Besse, F. Camara, C. Voirin, R. Auvergne, S. Caillol and B. Boutevin, Polym. Chem., 2013, 4, 4545-4561.

19 H. Zhang, H. Liu and J. Yue, Chem. Rev., 2014, 114, 883-898. 20 J. W. Comerford, I. D. V. Ingram, M. North and X. Wu, Green Chem., 2015, 17, 1966-1987.

21 F. Della Monica, B. Maity, T. Pehl, A. Buonerba, A. De Nisi, M. Monari, A. Grassi, B. Rieger, L. Cavallo and C. Capacchione, ACS Catal., 2018, 8, 6882-6893.

22 K. A. Andrea, T. R. Brown, J. N. Murphy, D. Jagota, D. McKearney, C. M. Kozak and F. M. Kerton, Inorg. Chem., 2018, 57, 13494-13504.

23 A. Buchard, M. R. Kember, K. G. Sandeman and C. K. Williams, Chem. Commun., 2011, 47, 212-214.

24 M. A. Fuchs, T. A. Zevaco, E. Ember, O. Walter, I. Held and E. Dinjus, Dalton Trans., 2013, 42, 5322-5329.

25 E. Fazekas, G. S. Nichol, M. P. Shaver and J. A. Garden, Dalton Trans., 2018, 47, 13106-13112.

26 G. Bresciani, M. Bortoluzzi, F. Marchetti and G. Pampaloni, ChemSusChem, 2018, 11, 2737-2743.

27 D. Alhashmialameer, J. Collins, K. Hattenhauer and F. M. Kerton, Catal. Sci. Technol., 2016, 6, 5364-5373.

28 M. Cozzolino, V. Leo, C. Tedesco, M. Mazzeo and M. Lamberti, Dalton Trans., 2018, 47, 13229-13238. 
29 F. Chen, N. Liu and B. Dai, ACS Sustainable Chem. Eng., 2017, 5, 9065-9075.

30 M. Taherimehr, S. M. Al-Amsyar, C. J. Whiteoak, A. W. Kleij and P. P. Pescarmona, Green Chem., 2013, 15, 3083-3090.

31 M. Taherimehr, J. P. C. C. Sertã, A. W. Kleij, C. J. Whiteoak and P. P. Pescarmona, ChemSusChem, 2015, 8, 1034-1042.

32 C. J. Whiteoak, B. Gjoka, E. Martin, M. Mart, E. C. Escuderoada, C. Zonta, G. Licini and A. W. Kleij, Inorg. Chem., 2012, 51, 10639-10649.

33 X. Sheng, L. Qiao, Y. Qin, X. Wang and F. Wang, Polyhedron, 2014, 74, 129-133.

34 O. J. Driscoll, C. H. Hafford-Tear, P. Mckeown, J. A. Stewart, G. Kociok-Köhn, M. F. Mahon and M. D. Jones, Dalton Trans., 2019, 48, 15049-15058.

35 F. Della Monica, M. Leone, A. Buonerba, A. Grassi, S. Milione and C. Capacchione, Mol. Catal., 2018, 460, 46-52.

36 F. Della Monica, A. Buonerba, V. Paradiso, S. Milione, A. Grassi and C. Capacchione, Adv. Synth. Catal., 2019, 361, 283-288.

37 O. J. Driscoll, C. K. C. Leung, M. F. Mahon, P. McKeown and M. D. Jones, Eur. J. Inorg. Chem., 2018, 5129-5135.
38 J. A. Stewart, P. Mckeown, O. J. Driscoll, M. F. Mahon, B. D. Ward and M. D. Jones, Macromolecules, 2019, 52, 5977-5984.

39 A. Stopper, J. Okuda and M. Kol, Macromolecules, 2012, 45, 698-704.

40 A. Stopper, K. Press, J. Okuda, I. Goldberg and M. Kol, Inorg. Chem., 2014, 53, 9140-9150.

41 E. L. Whitelaw, G. Loraine, M. F. Mahon and M. D. Jones, Dalton Trans., 2011, 40, 11469.

42 E. L. Whitelaw, M. G. Davidson and M. D. Jones, Chem. Commun., 2011, 47, 10004-10006.

43 S. M. Kirk, G. Kociok-Köhn and M. D. Jones, Organometallics, 2016, 35, 3837-3843.

44 P. McKeown, M. G. Davidson, J. P. Lowe, M. F. Mahon, L. H. Thomas, T. J. Woodman and M. D. Jones, Dalton Trans., 2016, 45, 5374-5387.

45 A. W. Addison, T. N. Rao, J. Reedijk, J. Van Rijn and G. C. Verschoor, J. Chem. Soc., Dalton Trans., 1984, 1349-1356.

46 J. A. Castro-Osma, M. North, W. K. Offermans, W. Leitner and T. E. Müller, ChemSusChem, 2016, 9, 791-794.

47 M. Cozzolino, T. Rosen, I. Goldberg, M. Mazzeo and M. Lamberti, ChemSusChem, 2017, 10, 1217-1223. 